вектора скорости результирующего воздушного потока вихревой колонны несущего винта предложено использовать неподвижный комбинированный приемник, выполненный по двухканальной схеме, включающий ионно-меточный и аэрометрический каналы измерения величины и угла направления вектора ветра.

В качестве ионно-меточного канала предложено использовать панорамный ионно-меточный датчик аэродинамического угла истинной воздушной скорости [1], обеспечивающий измерение скорости и угла направления вектора ветра на стоянке до запуска силовой установки.

На стоянке при запуске силовой установки и вращения несущего винта, при рулении и маневрирование по земной поверхности, на взлетно-посадочных режимах в работу включается второй - аэрометрический канал, выполненный на основе неподвижного полусферического аэрометрического приемника, жестко установленного над платой приемных электродов ионно-меточного датчика аэродинамического угла и воздушной скорости. На поверхности полусферической аэрометрического приемника расположены отверстия для восприятия давлений, несущих информацию о величине и угловом положении вектора скорости результирующего воздушного потока вихревой колонны несущего винта, по которой по разработанным алгоритмам вычисляются параметры вектора ветра.

1. Арискин Е.О., Кузнецов О.И., Никитин А.В., Солдаткин В.В., Солдаткин В.М., Фундаментальные и прикладные проблемы техники и технологии, №1(309), С. 122-132. (2015)

\title{
PHASE FLUCTUATIONS IN TWO COAXIAL QUASI-ONE-DIMENSIONAL SUPERCONDUCTING CYLINDRICAL SURFACES SERVING AS A MODEL SYSTEM FOR SUPERCONDUCTING NANOWIRE BUNDLES
}

\author{
Wong C. H. ${ }^{1}$, Wu R.P.H. ${ }^{2}$, Lortz R. ${ }^{3}$ \\ ${ }^{1}$ Institute of Physics and Technology, Ural Federal University, Russia \\ ${ }^{2)}$ Department of Applied Physics, The Hong Kong Polytechnic University, Hong Kong \\ ${ }^{3)}$ Department of Physics, Hong Kong University of Science and Technology, Hong Kong \\ *Email: ch.kh.vong@urfu.ru
}

The dimensional crossover or the phase transition of the weakly-coupled coaxial quasi1D superconducting cylinders will be studied via 8-state 3D XY model with help of heat capacity as a series of temperatures. The periodic dimensional crossover temperature $\mathrm{T}_{\mathrm{DC}}$ is observed by rotating the inner superconducting cylinder along the angular plane. The $\mathrm{T}_{\mathrm{DC}}$ is the highest if the relative angle between the cylinders is 2.81 degree. The phase fluctuations of the coaxial superconductors are controllable by the rotation and the weakest phase fluctuations are confirmed at 2.81 degree. In addition, the phase fluctuations are suppressed gradually upon cooling but the suppression suddenly becomes stronger appearing in the early stage of the dimensional crossover. Our model plays a significant role to investigate the way to 
suppress the phase fluctuations in the quasi-1D superconductors, in order to yield zero electric resistance below superconducting transition temperature.
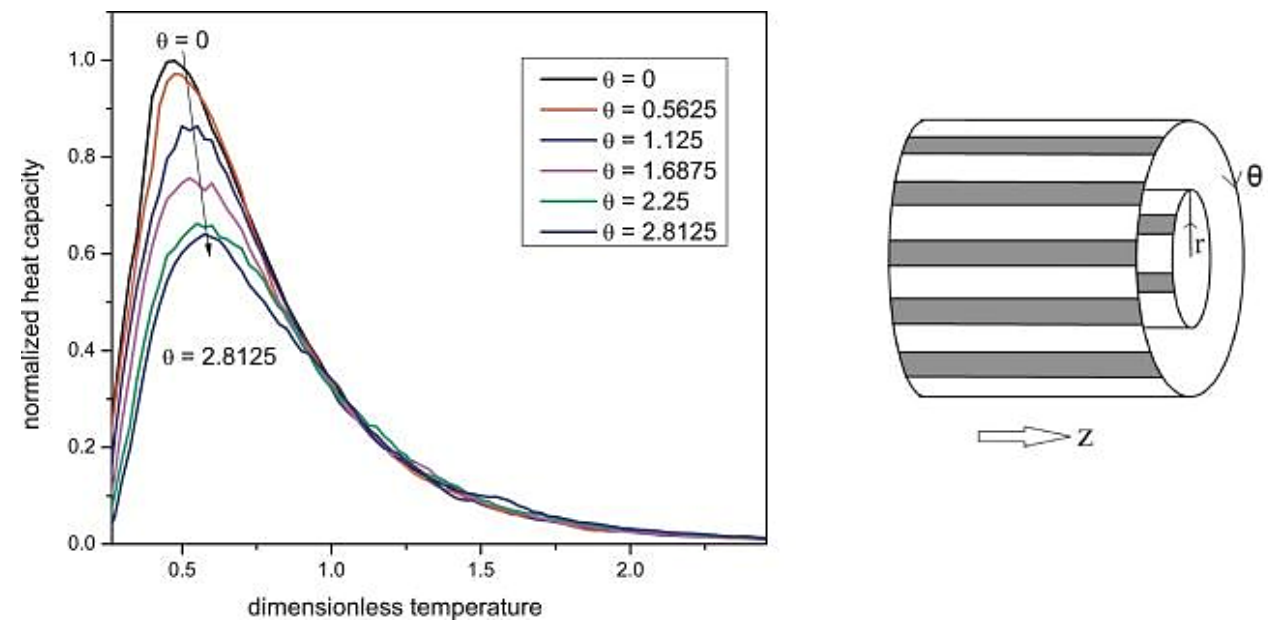

Fig. 1. The normalized heat capacity anomaly at different rotational angles $\theta$ between the inner and outer cylindrical surfaces as a function of dimensionless temperature

The highest transition temperature $\mathrm{T}_{\mathrm{DC}}$ occurs at $\theta=2.81^{\circ}$, which corresponds to the largest separation of the nanowires along the radial direction, but meanwhile the area under the curve is the smallest. At 0 and $5.62^{\circ}$ the nanowires have the smallest radial separation, and the lowest dimensional crossover temperature is found.

1. C.H.Wong, R.P.H.Wu, R.Lortz, Phase fluctuations in two coaxial quasi-one-dimensional superconducting cylindrical surfaces serving as a model system for superconducting nanowire bundles, Physica C, Volume 534, Pages 45-49 (2017)

\section{ОПТИЧЕСКИЙ СКАНИРУЮЩИЙ ПРОФИЛОМЕТР}

Соколенко Б.В. ${ }^{1 *}$, Полетаев Д.А. ${ }^{1}$, Халилов С. ${ }^{1}$, Погребная А.О. ${ }^{1}$

1) Физико-технический институт, «Крымский федеральный университет им. В.И. Вернадского», г. Симферополь, Россия

*E-mail: simplex@ crimea.edu

\section{OPTICAL SCANNING PROFILOMETER}

Sokolenko B.V. ${ }^{*}$, poletaev D.A. ${ }^{1}$, Khalilov S. ${ }^{1}$, Pogrebnaya A.O. ${ }^{1}$

1) Institute of Physics and Technology, «V.I. Vernadsky Crimean Federal University», Simferopl, Russia

Annotation. In this report we apply a new laser scanning profilometer and review principles and applications of using an optical vortex in high spatial resolution metrology at nanoscale three-dimensional regime. The phase-shifting technique with coherent LaguerreGaussian beams demonstrates ability to examine profile of transparent and reflecting samples with high accuracy and resolution down to $1 \mathrm{~nm}$. 